\title{
THE UBER DRIVER IS NOT AN ENTREPRENEUR
}

\author{
LUCAS CASAGRANDE ${ }^{1}$ \\ (iD) https://orcid.org/0000-0002-8327-4810 \\ MARTÍN A. M. ZAMORA ${ }^{1}$ \\ (iD) https://orcid.org/0000-0001-9015-2742 \\ CARLOS F. T. OVIEDO ${ }^{1}$ \\ (iD) https://orcid.org/0000-0002-4622-8372
}

To cite this paper: Casagrande, L., Zamora, M. A. M., \& Oviedo, C. F. T. (2021). The Uber driver is not an entrepreneur. Revista de Administração Mackenzie, 22(2), 1-24. doi:10.1590/1678-6971/ eRAMG210003

Submission: Jan. 23, 2020. Acceptance: July 6, 2020.

Federal University of Rio Grande do Sul (UFRGS), Porto Alegre, RS, Brazil.

\section{(c) $\mathrm{BY}$}




\section{ABSTRACT}

Purpose: To analyze the conceptual relationship between entrepreneurship and the Uber driver since the company is the pinnacle of a new way of organizing work. It is argued here that, contrary to what is used in numerous articles and in the media, the Uber driver is not an "entrepreneur" but a precarious worker with flexible facilities.

Originality/value: With the emergence of a new type of employment contract that is referenced in the labor relations of the company Uber, it becomes necessary to discuss the impacts of this new organization of labor. The conceptual discussion about the framework of the Uber driver is still incipient in the field. The research contributes to a better understanding of the discourse that the worker understood as an entrepreneur legitimizes exploitation.

Design/methodology/approach: This is a theoretical-analytical article. Historical and theoretical literature was used to weave how the concept of entrepreneurship emerges historically and changes over time. Also, Uberized labor is compared to Taylorism and Toyotism.

Findings: It demonstrates how the Uber driver cannot be considered an entrepreneur in any of the historical concepts. It is also demonstrated that the driver is a precarious employee, with flexible time and automated management, incorporating elements of the work organization of both Taylorism and Toyotism.

\section{KEYWORDS}

Entrepreneur. Uber. Uberization. Precarization of labor. Work flexibility. 


\section{INTRODUCTION}

The world of labor has changed significantly in the last years. Its consequences on organizations and society are still in course. Zero-hour contracts become more usual as the transactional costs decrease dramatically, mainly due to the use of the internet and smartphones, making it possible for anyone to communicate with anyone at any time.

This phenomenon, commonly called uberization, is, in fact, more profound than the mere widening usage of zero-hour contracts. It is the result of a subjective introjection of a new form of labor. In this new form, a myriad of concepts is used. In this article, we will focus on a concept widely used to describe this new way of working: entrepreneurship. Countless articles, both scientific (i.e., Bianquis, 2016; Nascimento, 2016; Padilha, Stein, \& Lemos, 2017; Bakker \& Salgado, 2016; Abílio \& Machado, 2017) ${ }^{2}$ And in the leading Brazilian newspapers have used the term "entrepreneur" to refer to workers such as the Uber driver. Furthermore, as of 2019, drivers can legally register themselves as "individual micro-entrepreneurs" (MEIs) to exercise their professions. However, there is a need to discuss what it is to be an entrepreneur and its meanings.

In this paper, we discuss the concept of uberization and entrepreneurship. We argue that there is an incommensurability between these concepts. To do so, we trace the history of the concept of "entrepreneur" and analyze the phenomenon of uberization. In this way, we can understand the implications and impossibilities of treating them together.

The global economic context places entrepreneurship as a social panacea. The growing interest in entrepreneurship is consequent to the consolidation of neoliberal policies in the last decades. Different efforts of governments, scholars, and neoliberal activists have been articulated by countless programs to encourage entrepreneurship in multiple ways and in publications that feed the legitimacy of the issue. These efforts naturalize entrepreneurship as the only economic possibility of entire populations and displace hope to its possibilities. Thus, the matter is of uttermost importance, as the signifier acquires contours of political figuration, requiring a precise meaning.

Moreover, the entrepreneurial phenomenon is widely accepted as a discipline and guiding concept. We will, initially, proceed to analyze what Uber

\footnotetext{
Several other close concepts appear, such as "micro-entrepreneur," "nano-entrepreneur," "entrepreneur of himself", among others. In this article, we will focus on the conceptual axiom, treating derivations as derived problems.
} 
is and how work is organized on this platform that has become the pinnacle for a new labor organization. From there, we will examine how the meanings of an entrepreneur have been conceptualized according to different contexts.

At this point, the notion of entrepreneurship will be examined as a concept resulting from a historical, socio-economic transformation. It happened initially through the Mercantile Revolution, then a second Industrial Revolution, and, finally, the rise of the neoliberal model. For this, the notions of entrepreneurship will be analyzed and which individuals are considered entrepreneurs as the concept becomes broader in time.

After that, we discuss the incompatibility of uberized labor as an entrepreneurial one in any of the concepts presented. Instead, the Uber driver is a precarious worker with flexible time and automated management. This is because, as we show in the last section prior to the Final Remarks, uberized labor is managed in a Taylorist logic but with an algorithm replacing the manager. Furthermore, it incorporates aspects of Toyotism, such as a just-in-time inventory system and the capture of the subjectivity.

\section{UBERIZATION}

The so-called uberization is consequent to the organization of labor that emerged with the Uber service of transport of passengers. Shortly after Uber was created, several other companies used this model, expanding to other kinds of services ${ }^{3}$. To understand this phenomenon, it is required to point out the innovations this model brings and how it operates. To do so, we remember that uberization is not a concept related to the labor relation in the company Uber, but a new way of organization of labor that was made popular by this company.

To begin its operations, Uber seems to have appropriated an idea in vogue at the moment: the collaborative economy, which would make them an app to manage hitchhiking. Later, Uber started to define that such hitchhikings were not gifts among strangers but a service provided in exchange for money - what the Western world calls "taxi" or "cab". But, of course, if this were their first announcement, it would be likely that more skepticism would be raised promptly (Slee, 2017).

The uberization of labor is already a global phenomenon, and it has shown itself included in other activities increasingly. Besides transport apps and delivery apps, other services are adhering to this model, such as cleaning services, animal caring, logistics, and the number grows. 
The service provided by Uber is made through a digital platform that connects drivers and consumers. Both of them register in the system and must be connected through the application. The passenger informs his/her location, and soon the Uber software finds the nearest driver available, who will meet him and begin his/her journey. Upon arriving at the destination, the driver ends the trip that informs him/her of the price of the operation.

When drivers register on the platform and start working, they become, at the same time, responsible for offering their labor and also for the tools required to produce the services they offer - the car, mainly, but also the smartphone, the connection with the internet, fuel, insurance, cleaning, etc. From that moment on, he/she must adhere to a contract without negotiation. As soon as it starts to work, it is the application that defines which passengers he/she must attend. The driver cannot find customers by him/ herself; he/she must passively wait for the application instructions. The moment he/she accepts a ride, he/she doesn't know who the passenger is, nor what the destination is, only knowing the information when he/she picks the passenger. How much the customer pays and how much the driver receives are defined by the platform's algorithm.

The drivers are rated by their customers. According to the grade received, the driver can be suspended or disconnected from the service. There is yet another reason that can lead to the partial or total disconnection of a driver, which is the refusal of calls. Each driver has a maximum number of services he/she can refuse.

Is it possible to understand as subordination the relationship of drivers with the platform? Uber has denied it (Pelegi, 2019). According to the company, drivers are not employees but "partners" because they own their vehicles and, thus, do not sell their workforce in exchange for regular payment in the form of wages. In this way, drivers sell a service paid for by those who consume it: passengers. The fee that must be paid to Uber is a remuneration to the platform for its mediation. Besides, it is the drivers who decide when and for how many hours they will be connected to the platform receiving passenger calls. Finally, drivers choose in which platform they want to work. By the logic presented, it is possible to conclude that it is not Uber that hires drivers, but it is the drivers that hire Uber services.

This argument, presented by Uber, is not a consensus among drivers or researchers. The company, among other similar platforms, has been the target of protests from workers who demand better working conditions. It is the case of the strike on May 8, 2019, in several countries, including the United States and Brazil. In São Paulo, this made the price of rides go up (Lobel, Pamplona, Oliveira, \& Dall'Agnol, 2019). 
Fontes (2017) points out that companies like Uber do not directly own the tools and the means of production. Still, they have strict control over the workforce, the means of production, and the consumer market without a work contract. For the author, what Uber holds is the ownership of resources of social production. These initiatives accelerate the transformation of the employment relationship into isolated work directly subordinated to capital, devoid of rights. Far from reducing the importance of capitalist property, uberization enhances it.

According to Franco and Ferraz (2019), uberization produces a new way of mediating worker subsumption. The worker assumes responsibility for the primary means of production. For the authors, the fact that there is no previously fixed working day does not disappear with the roles of buyer and seller of the workforce. What is changing is that the capital that should be advanced by the company in the condition of constant capital is now required from the worker. Based on the concept of salary per part, they understand that it is a "salary per ride".

From the moment the worker turns on his app until the moment he turns it off, his work is controlled by the company that owns the platform that determines each aspect of the work. Even the length of the working day is defined by the economic imperative: the need to work long hours, above eight hours a day (André, Silva, \& Nascimento, 2019).

The organization based on uberized labor makes the disposition of the worker extremely flexible. He will only be called when there is a demand for his profile related to his location and vehicle type. At the same time, platform workers are totally deprived of any social protection without contributing to social security and unemployment - unless they do it on their own - without having night overtime, overtime, additional salary at the end of the year, paid vacation, and even insurance. When the worker is disconnected from the platform, parting occurs without any prior notice. It is as if the worker never existed!

\section{WHAT IS AN ENTREPRENEUR?}

It is crucial to understand what the concept "entrepreneur" means to be able to grasp new phenomena of the labor world. The idea of entrepreneurship arises with mercantilism, even being used as an ordinary word, previously to Richard Cantillon (1680-1734). Since then, the concept has been readapted, reused, and changed, but it keeps something in common: 
the legitimizing purpose of economic relations that become effective. It is instrumental in each historical moment of a project of society. Thus, the conceptual rigor that we advocate here is not merely for a scholarly exercise but a necessary means to analyze reality with more significant emancipatory potential.

Jones and Spicer (2009) argue that "entrepreneur" is an empty shell that lends itself to occupy a role in the capital relations matrix. This role pays and makes it possible to live materially. Still, it also requires the only thing that has remained since the beginning: the idea of an excess of production in situations in which a "non-entrepreneur" would not see the same need. In this sense, the entrepreneur assumes the role of maintaining a circulating economy through profligacy. This was originally at odds with the subsistent ways of life, tending to legitimize those who attribute material possibilities to the market.

Even starting from the analysis that the entrepreneur is only a concept that legitimizes capitalism through excess, the idea of the Uber driver as an entrepreneur seems to escape it. For this reason, we make a genealogy of the concept below and establish three historical moments and their concepts. We are not assuming that the concepts discussed below were unanimous in their historical moments, nor that there were no other conceptualizations, but that we are, for analytical purposes, treating the idea of entrepreneurship as a historical evolution pari passu with capitalism.

\subsection{The conceptual primordium: Cantillon}

Etymologically, "entrepreneur" comes from the medieval French word "enterprendre," which meant "to do something". It derives from the roots "in" (inward) and "prendère", which can also be interpreted as "taking for yourself". As an adjective, according to Hoselitz (1951), it attributed the quality of a highly active person. Thus, we can say that in the course of a millennium, the word does not seem to have lost its initial spirit, although its meaning seems to derive, as we shall see.

Richard Cantillon, born in 1680 in Ireland, and a French immigrant, seems to be the first theorist to focus on the concept of entrepreneur and its meaning. With a very aggressive commercial background, Cantillon writes his famous Essai sur la nature du commerce en général, published later, in 1756. For him, the entrepreneur was like a kind of market activator. Thanks to this, the market comes out of its inertia. Unlike authors like Adam Smith (1723-1790), his entrepreneurial view was not based on a self-regulating market idea but on a market that continually tends to an inertia that is 
broken by the entrepreneur (Murphy, 1986). Of course, his vision was derived from the opposition to a subsistent life and, therefore, alien to the market - something familiar to its historical context marked by ideas of modernity.

For Cantillon, the central feature was the uncertainty of his activity. In a way, the entrepreneur was a kind of gambler who bet on a commodity that he believed he valued, either because of time or because of distances. As a man of his time, Cantillon understood the transhistorical economic nature as a process of progressive decentralization. Initially, he realized that the economy was centered on a few figures - feudal lords, the Church, and those who control land ownership. Over time, entrepreneurs enter the scene in Europe and take risks through trips that enable information asymmetries and, with that, risk and profit.

It is clear that Cantillon's vision of the entrepreneur borders on adventurous idealization, which we can visualize in Marco Polo (1254-1324), the entrepreneur-explorer of markets. In his time, Marco Polo had risked his own life on trips that lasted months and even years, taking spices and silk from the extreme east to Europe. For this, he crossed desert regions controlled by the hashashins, met and became fond of the Mongol emperor Kublai Khan (grandson of Genghis Khan), sailed the Mediterranean and the Arabian, crossed Persia, and went to what is now Myanmar, China, Singapore, Indonesia, and Sri Lanka. In his time, Marco Polo did what was unimaginable to many (Polo, 1996).

The Venetian merchant's great feat was not to get rich - although he also did - but to cross half the planet, dealing with such different cultures and with such high risks. The entrepreneur was an agent of social and economic transformation, an inhabitant of the social imagination. He was the man who brought to the vernacular world the idyllic histories of unreachable earthly wonders. Cantillon's entrepreneur was not the only one who took the risk of bankruptcy - he was the one who took the risk of dying from starvation, violence, or accidents from an unknown world.

Cantillon gave new dimensions to the concept of the entrepreneur. Its function in the market was to stabilize the value of the goods at their "intrinsic value." In doing so, the entrepreneur, as a trader, generates high demands for poorly produced products, increasing the advantage of providing them and thus encouraging the market to make them (Murphy, 1986). Moreover, Cantillon's entrepreneur acted as a substitute for a central controller, creating a demand for resources. Thus, it appeared as Adam Smith's invisible hand in the classic question of the resource allocation problem. He was contrasting 
an emerging model of capitalism with a feudal model in ruins. Therefore, the entrepreneur is not only a market function or even an adventurer who inhabits tales and the imaginary; it is a symbol of the celebration of emerging capitalism, incipient capitalism.

Cantillon was using the concept, even then, as a discursive wrapper, as an ideological apparatus. The European historical moment was the modern formation, the Industrial Revolution, the enclosure of the herds, and the constitution of a male/female apartheid as the one who works outside and the one who works at home. It was the constitution of the social logic that we know today, based on proto-industrial heteronomy, but at that time at war with vernacular values, with subsistence, and with autonomy (Illich, 1981).

In this historical context, the entrepreneur is a praiseworthy, apologetic, and celebratory concept of a new world, of the incipient modern capitalism.

\subsection{The classic concept: Schumpeter}

In a subsequent historical moment, which we can situate as part of the Second Industrial Revolution, the transition between the 19th and 20th centuries, the concept of entrepreneurship returns as what today is considered classic, linked to the social imaginary as derived from an innovative process. The liberal thinking of that historical moment centered a significant part of its economic vision on Léon Walras (1834-1910).

According to the proposer of the General Equilibrium Theory, the market could be understood in the big auction metaphor, where prices would tend to balance as long as its performance was not restrained. In other words, at the limit, the market would balance and consolidate in a watertight manner, progressively reducing profits (Walras, 1996). Under this metaphor, the market, once freed, would be structuring human wills, and, finally, the process of the human agency would be no more than finding loopholes in hidden auctions. Elements, such as technological development, are not considered in the economic model and are, therefore, understood as exogenous factors.

Then the figure of Joseph Alois Schumpeter (1883-1950) comes in. The Schumpeterian thought emerged to complement current economic theories, such as static models of Walrasian equilibrium. Such models, which always tended to be in full balance, come to have a deadly enemy: the entrepreneur (Swedberg, 2000).

For Schumpeter (1981), the entrepreneur triggers the truly significant changes in the economy. These changes develop slowly through the economic system, in the form of a business cycle. Schumpeter (1981) also suggested 
that this idea of change produced internally, as opposed to change induced from abroad, was applicable not only to economic phenomena but also to all social aspects. Thus, economic development is not limited to the growth of the output of an economy. It presents itself as a spontaneous and discontinuous change that alters and displaces the previous state of equilibrium (Costa, Barros, \& Carvalho, 2011). Schumpeter (1981), therefore, advocates a dynamic analysis of the economy.

This new theory of economic dynamics is centered on the entrepreneur's figure as an agent of innovation. To be worthy of this title, it is not enough to invest capital in any business. The Schumpeterian entrepreneur is responsible for developing new products for the market through innovations in the most efficient combination of production factors. Thus, the author arrived at the following typification of innovation: 1. introduction of a new good; 2 . introduction of a new production method; 3 . opening a new market; 4 . the conquest of a new source of raw material; 5 . creation of a new organization for any industry (Swedberg, 2000).

Unlike marginalist thinking, these innovations do not seek balance; on the contrary, they disturb the established balance, and the subject of this transformation is precisely the entrepreneur. Hence the concept of creative destruction, which is the introduction of disruptive and innovative technologies. It provides productive leaps but destroys old ways of producing, such as the car did to the horse riding, the computer to the typewriter, or industrial robots to workers.

If Cantillon and his concept were in vogue in a historical moment that the bourgeoisie was ascending and gradually replacing the feudal aristocracy, Schumpeter and his entrepreneur enter the scene to legitimize the industrialists who promoted the Second Industrial Revolution. The assembly lines were constituting, on the one hand, a productive leap, but on the other, a substantial change in the way of life. The entrepreneur was the figure that made it acceptable, palatable at that historic moment. It was the messenger of Schumpeter's novelty.

\subsection{The current concept: entrepreneurial neoliberalism}

In its current stage, neoliberal capitalism assigns an agent the role of catalyzing resource allocation and competition. The new concept of entrepreneur, postulated by Kirzner $(1973,1997)$, describes the one who finds gaps between supply and demand, acting on supply gaps and, thus, normalizing the market through an uncertain future bet. In this sense, what characterizes 
the entrepreneur is his permanent alertness to identify business opportunities in the market. It is a matter of individual perception, from which the entrepreneur takes advantage of opportunities and reestablishes the balance between demand and supply. The entrepreneur's supposed virtues are central to the moral rejuvenation of entrepreneurship and, thus, of capitalism itself. In this process, values such as taking risks and self-sufficiency are internalized in each of us in individual accountability (Hanlon, 2014).

Although the central figure here is Kirzner $(1973,1997)$, several authors contribute to the neoliberal vision of the entrepreneur, such as Hayek (1945, 1948) and Mises (1996). It is also actively disseminated in the scope of Economics Science by Casson $(1982,2005)$ and in Management and Business Schools by Drucker (1987). In Hayek $(1945,1948)$, the entrepreneur's figure appears practically, a doer, a being provided with practical knowledge and who ignores theories and the abstract world. In Mises (1996), the entrepreneur is central for the economy to flow. His argument sometimes resembles Schumpeter's in that there is an assumption of a stable market that needs the figure of the entrepreneur to renew itself. However, Mises (1996) argues that the entrepreneur is the figure who anticipates uncertain events - and not the character who innovates through creative destruction (Swedberg, 2000).

In addition to these theoretical differences, our analysis here sees material consequences. After all, the production of a theory is not just a reflection on how reality operates, but rather on applied social sciences - it produces a reality through the performativity of a discourse. In this sense, the model that Hanlon (2014) calls "finders-keepers", propagated by the Austrian economic school and spread by the current notion of entrepreneurship, produces a world where profit - and in the neoliberal state, therefore, survival itself - depends on predicting market instabilities.

And although the error is central to this neoliberal entrepreneurial vision, its predication occurs with a negative connotation. Thus, the entrepreneur emerges as the model of economic salvation and as a process of population ecology, which incorporates a social Darwinism, where few get it right and are successful. At the same time, those who made mistakes are repeatedly advised to try again -- without any collective accountability. As Ortega (2014) points out, the concept of the neoliberal entrepreneur has become a moral imperative.

As Costa et al. (2011) contextualize, neoliberal public policies are shaped around the world from the Washington Consensus. The entrepreneur acquires a central role in the economy, being a key concept no longer 
willing to rare and disruptive members of society, but to all of us. We must all be doers, projecting ourselves into the future.

The authors demonstrate that contemporary entrepreneurship acquires moral contours as a phenomenon that needs to reach social totality. For this to happen, the entrepreneur becomes no longer a way of living but a legitimate form of living. Work must cease to be a means to achieve a good life and becomes an end in itself.

But even the neoliberal concept of entrepreneur, as a very broad one that embraces as much as possible, does not seem to designate the Uber driver. It is not enough to do something in order to be an entrepreneur. Otherwise, everyone would be one. What identifies the neoliberal entrepreneur is the willingness to seize opportunities and acts in anticipation of the market reaction. It is about reacting to the market before the market makes the auction. And, as the future is uncertain by nature, only the creative agency can handle this feat.

But the Uber driver is not betting. He goes where it is designated, and he does what is commanded. The only autonomy he keeps is to choose his working times. Based on these three concepts, we outline below a conceptual scheme:

\section{(Figure 3.3.1)}

\section{ENTREPRENEURSHIP CONCEPTS}

\begin{tabular}{|c|c|c|c|}
\hline & Original entrepreneur & Classic entrepreneur & Neoliberal entrepreneur \\
\hline Central author & Richard Cantillon (1756) & Schumpeter (1981) & Kirzner $(1973,1997)$ \\
\hline $\begin{array}{l}\text { Historical } \\
\text { context }\end{array}$ & $\begin{array}{l}\text { European mercantilism, } \\
\text { commercial bourgeoisie } \\
\text { ascendance in Europe. }\end{array}$ & $\begin{array}{l}\text { Formation of corporations, } \\
\text { factory mechanization, } \\
\text { assembly line, the rise of } \\
\text { the western industrial } \\
\text { bourgeoisie. }\end{array}$ & $\begin{array}{l}\text { Destruction of the welfare } \\
\text { state in Europe; } \\
\text { neoliberalism. }\end{array}$ \\
\hline $\begin{array}{l}\text { Entrepreneur } \\
\text { characteristics }\end{array}$ & $\begin{array}{l}\text { Adventurous, takes } \\
\text { risks (even risking his } \\
\text { life), travels long } \\
\text { distances, creates } \\
\text { markets. }\end{array}$ & $\begin{array}{l}\text { Innovator, creates new } \\
\text { ways of production or } \\
\text { new forms of selling, } \\
\text { even by destroying the } \\
\text { old ways (creative } \\
\text { destruction). }\end{array}$ & $\begin{array}{l}\text { Precarious gambler; bets in } \\
\text { a future market without } \\
\text { enough information. The } \\
\text { economic environment } \\
\text { selects it according to his/ } \\
\text { her success rate (ecological } \\
\text { selection). }\end{array}$ \\
\hline $\begin{array}{l}\text { Who is the } \\
\text { entrepreneur? } \\
\text { (examples) }\end{array}$ & Marco Polo & Henry Ford & $\begin{array}{l}\text { The owner of the closest } \\
\text { food truck. }\end{array}$ \\
\hline
\end{tabular}




\section{(Figure 3.3.1 (conclusion))}

\section{ENTREPRENEURSHIP CONCEPTS}

\begin{tabular}{clll} 
& Original entrepreneur & Classic entrepreneur & Neoliberal entrepreneur \\
\hline $\begin{array}{c}\text { Is Uber driver } \\
\text { an entrepreneur }\end{array}$ & $\begin{array}{l}\text { No, because he/she } \\
\text { does not take life risks }\end{array}$ & $\begin{array}{l}\text { No, because he/she does } \\
\text { not create new forms of }\end{array}$ & $\begin{array}{l}\text { No, because he/she does } \\
\text { not gamble in a future }\end{array}$ \\
& $\begin{array}{l}\text { asymmetry of } \\
\text { information. }\end{array}$ & production or market - it & market and it is not \\
does not innovate. & & \\
\hline
\end{tabular}

Source: Elaborated by the authors.

Even being a legitimizing concept of the new ways of capital accumulation, the entrepreneur's notion was stretched beyond its limits as the times goes by. Initially, it appears to be a concept that had emerged from the new commercial elites that required a new moral in opposition to the idea that they were unproductive. After that, the concept was changed insofar, and a new kind of bourgeoisie grew with the second industrial revolution. Currently, the concept is useful to legitimize the precarious despair of those who seek an income. The neoliberal entrepreneur is the one who takes the daily financial risk, i.e., the hot dog seller who needs to imagine what place with the highest demand today is; it is the salesman who gambles which products will be desired tomorrow.

At first glance, the Uber driver indeed seems to be this precarious neoliberal entrepreneur. But even this broad concept still requires an idea of human agency. After all, the entrepreneur takes risks, bets on an uncertain market. But does the driver, guided by the algorithm, still bet? As far as we can grasp, no. Its work is to follow what the app commands. Even in low demand moments, the driver can watch, through the app, where high demand is and go there. It is not of any creative agency but a conditioned behavior. It is so that Uber's current big project seems to be robotizing the entire fleet (O’Kane, 2019).

If the Uber driver is not an entrepreneur, as we argue, we should have some categories to understand what he is conceptually. To do so, we should separate what differs the Uber worker from the usual company employee.

The first criterion would be that uberized workers, contrary to the typical employee, must have their work tools, which can sometimes be confused as the means of production. The lack of this distinction is what produces the belief that this is entrepreneurship. However, it is essential to note that the actual mean of production is the app, the platform. A car is only a tool 
of production here. The requirement of being responsible for the tools of production is only a typical feature of precarious labor - not a hallmark of entrepreneurship.

A second criterion is that an Uber driver receives, unlike a typical employee, according to his/her production, usually based on mileage, time, and dynamic fares. In similar cases, in which the product is not transportation, the factors are basically "produced pieces" (being "pieces" as an abstract generality) and time spent. Here, it should be noted that the contract payment is not new in salaried work, having even been used by Taylor.

A third criterion is that the uberized worker has freedom in time (how long he will work and what hours). But he does not have freedom inside the work, answering calls without a choice between places, which people, tariff to charge, or any other variable. He may deny the job, but this will cause him to lose points on the platform, decrease his future calls, and result in his disconnection from the platform. This is an important criterion to distinguish uberized work from the mere precarious one since this is, in fact, a flexibility that uberized workers tend to ensure. However, this is not a particularly new production regime; it is actually the implementation of the availability of the toyotist just-in-time labor on a scale never imagined.

Finally, a fourth and final criterion is that the uberized person does not have a social protection system. There is no payment of social security benefits, no paid rest time, and the company does not cover sick days, medical disability, or any other protection type. It operates under the logic that the uberized person is not a worker but an equal partner of Uber, which is evidently false.

Based on these criteria and the entrepreneur concept's review, it becomes clear that the Uber driver is not an entrepreneur, not even for the broader concept of the three presented - not even for the most legitimizing concept of this current phase of capitalism. Instead, he/she is a precarious worker with time flexibility and automated management. This brings us to the question: if he is a worker, what regime of production is he subordinate to?

\section{ALGORITHM TAYLORISM, TOTAL TOYOTISM}

Uberization is Taylorism mediated by an algorithm that replaces, partially or entirely, managers. With cell phones and computers, Scientific Administration can go more in-depth on a scale never imagined by its precursor. Besides, uberization takes on total Toyotism with a mass of available 
workers just-in-time with their co-opted subjectivities. Here, we start from the idea that uberization is a generalizable phenomenon as a framework for labor organization (Ellmer, 2015).

Taylor (1990), when illustrating his innovative proposition of Scientific Administration, brings up the stevedore Schmidt, described as the ideal of homo economicus, accustomed to loading trucks with an iron according to his convictions of what movements to do and how to proceed. Taylor, however, realized - and this is the heart of his management proposition that micromanaging his workers would produce evident fruit since more efficient movements would replace expensive ones. Iron loading would no longer be a game for big, rough children, but instead, it becomes an operation made by machines made of meat.

Of course, this brought productive gains while increasing the cost of management. Now, the manager's job was no more than giving generic orders but managing even the workers' movements, which required more supervisors. This new cost also justified the decrease in the value per piece produced by Schmidt, who, despite this, still earned more at the end of the day for having loaded substantially more. The difference per piece arranged would go to this new management of movements. ${ }^{4}$

Now let's look at the productive change between taxi and Uber. The first goes back to a pre-Taylorist form of work: there is a relative autonomy of the taxi driver, there is an absence of micromanagement. Over time, taxi companies around the world started to create phone services, that is, work management that increased the taxi's efficiency, moving cars to demand points. However, as with Taylor, this, while increasing efficiency, created a cost, making it a partial solution.

If the taxi required some agency from the driver (because he needed to imagine where there would be a demand at a given time and the best routes), the Uber driver is reduced to small movements prescribed by an application. The perception that what is often called a gig economy or platform economy (Moraes, Oliveira, \& Accorsi, 2019) is an updated Taylorism (Ellmer, 2015). Amazon's Mechanical Turk platform is a precursor to this movement.

Ellmer (2015) states that the Taylorist method is based on reallocating production knowledge, removing it from workers, and concentrating expertise and, therefore, the direction of work in a kind of automated work

According to Taylor, Schmidt carried 12.5 tons of iron a day and started to load 47 with his new method. However, his daily wage increased in a non-linear manner: before the new method, about 9 cents per ton. After that, about 4 cents per ton. The total salary increased, the payment per piece decreased - the difference would go to management cost (and, presumably, to increase profit). 
bureau. Taylor broke work down into small tasks managed in real-time, separating work between those who made the physical and those who made the mental one. Consequently, the workers lose power and autonomy in favor of higher efficiency managed by superiors. In turn, these started to standardize the steps and make complex activities into countless simple activities (Ellmer, 2015).

This Taylorist process is precisely what occurs in the uberization of labor, but with two aggravating factors. The first is the division of labor between mental and physical work, but instead of managers and blue-collars, we have algorithms and drivers. Secondly, the platform records the work to the point that, as widely reported, Uber plans to make cars that drive themselves, using the behavior of the drivers who used to work for the company. But while that doesn't happen - if it ever does - the problem is that the worker becomes a robot that responds to expected stimuli (Spencer, 2018).

Therefore, it is also necessary to clarify that the uberized person is also not a self-managed worker, as Abílio (2019) argues. ${ }^{5}$ The author's article, portraying the Uber driver as "self-managed," brings improvements over the driver's concept as an "entrepreneur" since the manager is also an employee. In this sense, the author leaps, recognizing that the worker is, in fact, a precarious employee. The problem is that Abílio (2019) takes the phenomenon at face value when interpreting the drivers' discourse that they manage themselves because they have flexible hours. In reality, it should be clear that the driver does not manage anything beyond what a taxi driver does. Even worst, it loses any autonomy over which passengers to take, where, how much to charge, whom to accept, and even which routes to take. Management is, of course, made by the company's algorithm. The application automates the management function.

The uberization can achieve the Toyotist dream of the just-in-time worker: the working day is indefinite, and the labor universe is always available due to the economic imperative. Simultaneously, the remuneration of the worker only occurs when he is doing some work for the company, in the same way as in the salary per piece, as pointed out by Franco and Ferraz (2019). It allows capital to count with a large contingent of available workers without paying absolutely anything for its availability. The workforce is only paid when work is done.

Abílio's article is also problematic in another sense. By using the self-management concept, it promotes a theoretical-political movement to capture the idea of self-management in favor of precarious work. Here, it is worth noting, self-management is a concept historically linked to movements of emancipation and liberation, as Vieta (2014) describes in his libel by an organizational prefiguration. 
There is also a deepening of shadow work, which, according to Illich (1981), is the work needed for accumulation but is unpaid. If in Taylorism, control was a task restricted to management, and in the first phase of Toyotism, it was shared with workers (Gounet, 1999), control is now exercised in an unpaid manner by the consumer himself. Purchaser assessment feeds into the platform's algorithm that is programmed to punish or reward the work analyzed.

In the case of Uber drivers, even pushing drivers to the places of highest demand is done through dynamic tariff incentives. Thus, uberization uses a system of positive and negative stimuli to carry out work management, as if the worker were a laboratory rat or Pavlov's dog. The human creative agency, which is so necessary to the concept of entrepreneurship, is suppressed in favor of what Guerreiro Ramos (1981) calls behavioral syndrome. It is the suppression of creative action substituted by behavior based on rewards and sanctions.

Finally, uberization demands that the worker should have both the skills and the tools for their work. Thus, the smartphone and the car are integrated into a service production circuit along with individual skills, becoming the worker's responsibility. It is the uberized worker who finds himself obliged to assume the operational expenses of the services he provides and to assume the risks. As Fleming (2017) argues, this generates a mass of workers in constant debt, anxiety, and being held radically accountable. Accidents, theft, or even the death of the worker on duty are his sole responsibility.

The cooptation of subjectivity (Bianchini, 2017), an unequivocal characteristic of Toyotism, is also in place. According to André et al. (2019), in the interviews they conducted, they observed that some Uber drivers reproduced in their responses the company's slogans, despite having reported precarious working conditions such as low earnings and excessive driving hours. The authors also state that drivers believe they own their own business, demonstrating that the company was successful in the subjects' psychic involvement. This report confirms a condition of adjustment to the imaginary instituted by the organization, configuring cooptation through identification and kidnapping through total involvement (Bianchini, 2017; Faria \& Meneghetti, 2007).

There is an update of the Toyotism, as the cooptation of subjectivity stops occurring in a planned way by the organization (through human resource programs) and starts to happen in an automated way. The full subjective worker's donation is required to reach the maximum score of the application. 


\section{FINAL REMARKS}

Uberization is a new phenomenon, and, therefore, the reflection on what it means and its impacts are still incipient. Because of this, academic thought on this new way of organizing work seems to be even taking place. Our contribution here was to bring conceptual precision to the phenomenon so we can reflect on the social impacts in future articles.

We argue that the Uber driver is a worker - with specificities typical of new technological arrangements - and not, under any explored concept, an "entrepreneur," as many authors say. To conclude this, we contrast uberized work with the theoretical conceptions historically constituted of what it is to be an entrepreneur. We followed the path initiated by Cantillon (1756) up to the neoliberal concept (Kirzner, 1997), passing through Schumpeter's classic notion of the innovative entrepreneur (1981). There was a double purpose: on the one hand, we demonstrate that, from a conceptual point of view, treating the Uber driver as an entrepreneur does not give the term precision. But beyond that, the concern is that the word entrepreneur serves as a conceptual buffer for precariousness, providing legitimacy to any relationship of exploitation.

In this way, we demonstrated that the classic concept of an entrepreneur is linked to an idea of an almost heroic risk of crossing territorial spaces, bringing unique products. For this, the original entrepreneur is an adventurer who buys products in the hope that, after long journeys, he would be able to sell them at prices that, although not known, are expected to produce a profit.

Then, we presented the classic Schumpeterian concept. The entrepreneur was then a disruptive innovator who creates new ways of producing or new products by destroying the old ways. In this sense, it is possible to say that the Uber company is entrepreneurial, but never that the driver is.

Finally, in the neoliberal and prevailing concept, the entrepreneur is understood as someone who, through trial and error, anticipates market movements. The logic in this thought is that there is a kind of population ecology that will select entrepreneurs who know how to anticipate the market's change correctly and discard those who don't. Under this concept, it is possible to say that the autonomous taxi driver is an entrepreneur since he needs to anticipate the places of movement and seek uncertain markets. In this neoliberal concept of entrepreneur, there is a touch of creativity and inventiveness, although restricted to small betting actions. However, the 
Uber driver is expected to follow the app's demands rather than being inventive. The app rewards those who follow their commands through the dynamic fare and scoring system.

Thus, we can say that the Uber driver is not an "entrepreneur" in any historical or theoretical understanding. In this sense, we also warn that other conceptual propositions such as "subordinate self-managed" (Abílio, 2019) are also not very reliable to the phenomenon. Although this idea recognizes subordination, it seems that the work is managed by the driver himself, which is a mistake. One clue that these concepts do not apply to this new form of work is Uber's project to create self-driving cars. Instead of human agency, what is expected is precisely good behavior, as Guerreiro Ramos (1981) diagnosed as typical of modernity.

We affirm that the uberized person is not an entrepreneur but a precarious worker with flexible facilities. Beyond the ownership of the tools required to work and the absence of employer assistance, there are two variables to be explored. The first is the micromanagement made by an algorithm. The second, the availability of workers just-in-time.

The first goes back to Taylorism managed by, instead of a manager, an algorithm that automates, previously, human work. The second is typical of an in-depth Toyotism coopting workers' subjectivity (Bianchini, 2017; Faria \& Meneghetti, 2007).

Finally, there is a question explored marginally in this work, which could be a possibility for future studies: how does the imprecise concept of an entrepreneur facilitate the legitimization of the precarious work exploitation? It seems that such imprecision is not only a conceptual error. It is a dispute of meaning to legitimize exploitation.

\section{MOTORISTA DE UBER NÃO É EMPREENDEDOR}

\section{RESUMO}

Objetivo: Analisar a relação conceitual entre empreendedorismo e o trabalhador de aplicativo. Objetiva-se caracterizar conceitualmente o motorista da Uber, entendido como pináculo de uma nova forma de organizar o trabalho. Argumenta-se aqui que, ao contrário do que utilizado em inúmeros artigos e no senso comum, o motorista de Uber não é "empreendedor”, mas, sim, um trabalhador precário com facilidades flexíveis. 
Originalidade/valor: Com a emergência de um novo tipo de contrato de trabalho que se referencia nas relações laborais da empresa Uber, torna-se necessário discutir os impactos dessa nova organização do trabalho. A discussão conceitual sobre o enquadramento do motorista de Uber ainda é incipiente na área da Administração. Esta pesquisa contribui para um melhor entendimento de que o discurso do trabalhador subsumido ao empreendedor é legitimador de processos de exploração.

Design/metodologia/abordagem: Trata-se de um artigo teórico-analítico. Recorreu-se à literatura histórica e teórica para tecer como o conceito de empreendedorismo emerge historicamente e vai se alterando. Comparou-se o trabalho uberizado às formas clássicas de organização do trabalho, em específico, o taylorismo e o toyotismo.

Resultados: Demonstra-se como o motorista de Uber não pode ser considerado um empreendedor em nenhuma das conceituações históricas. Demonstra-se, também, que o motorista é um funcionário precário, com flexibilidade de tempo e gerência automatizada, incorporando elementos da organização do trabalho tanto do taylorismo quanto do toyotismo.

\section{PALAVRAS-CHAVE}

Empreendedor. Uber. Uberização. Precarização do trabalho. Flexibilização do trabalho.

\section{$\int$ REFERENCES}

Abílio, L. C. (2019). Uberização: Do empreendedorismo para o autogerenciamento subordinado. Psicoperspectivas, 18(3), 41-51. doi:10.5027/ psicoperspectivas-Vol18-Issue3-fulltext-1674

Abílio, L., \& Machado, R. (2017). Uberização traz ao debate a relação entre precarização do trabalho e tecnologia. IHU On-Line, (503), 20-28.

André, R. G., Silva, R. O. da, \& Nascimento, R. P. (2019). "Precário não é, mas acho que é escravo": Análise do trabalho dos motoristas da Uber sob precarização. READM, 18(1), 7-34.

Bianquis, G. (2016). Le chauffeur Uber, entrepreneur précaire? Regards croises sur l'economie, 2(19), 155-159. doi:10.3917/rce.019.0155 
Bakker, B., \& Salgado, J. (2016). "Quando a crise faz o empreendedor": Desemprego e empreendedorismo no jornal O Estado de S. Paulo. Revista de Comunicação e Cultura, 15(2), 590-608. doi:10.9771/1809-9386 contemporanea.v15i2.17858

Bianchini, C. (2017). Por que as portas fecham? Do capital às demissões em massa (Dissertação de mestrado, Universidade Federal do Rio Grande do Sul, Porto Alegre, Brasil).

Cantillon, R. (1756). Essai sur la nature du commerce en général: Traduit de l'anglois. Paris: Chez Fletcher Gyles.

Casson, M. (1982). The entrepreneur: An economic theory. Lanham: Rowman \& Littlefield.

Casson, M. (2005). Entrepreneurship and the theory of the firm. Journal of Economic Behavior \& Organization, 58(2), 327-348. doi:10.1016/j.jebo.2004. 05.007

Costa, A. M., Barros, D. F., \& Carvalho, J. L. F. (2011). A dimensão histórica dos discursos acerca do empreendedor e do empreendedorismo. Revista de Administração Contemporânea, 15(2), 179-197. doi:10.1590/S1415-6555 2011000200002

Drucker, P. F. (1987). Inovação e espírito empreendedor. São Paulo: Editora Pioneira.

Ellmer, M. (2015). The digital division of labor: Socially constructed design patterns of Amazon Mechanical Turk and the governing of human computation labor. Momentum Quarterly, 4(3), 174-186.

Faria, J. H., \& Meneghetti, F. K. (2007). O sequestro da subjetividade. In J. H. Faria (Ed.). Análise crítica das teorias e práticas organizacionais (pp. 45-67). São Paulo: Atlas.

Fleming, P. (2017). The human capital hoax: Work, debt and insecurity in the era of Uberization. Organization Studies, 38(5), 691-709. doi:10.1177\% 2F0170840616686129

Fontes, V. (2017). Capitalismo em tempos de uberização: Do emprego ao trabalho. Revista do NIEP-Marx, 5(8), 45-67.

Franco, D. S., \& Ferraz, D. L. da S. (2019). Uberização do trabalho e acumulação capitalista. Cadernos EBAPE.BR, 17, 844-856. doi:10.1590/1679395176936

Gounet, T. (1999). Fordismo e toyotismo na civilização do automóvel. São Paulo: Boitempo.

Guerreiro Ramos, A. (1981). A nova ciência das organizações: Uma reconceituação da riqueza das nações. Rio de Janeiro: Fundação Getulio Vargas. 
Illich, I. (1981). Shadow Work. In I. Illich. Shadow Work. New York: Marion Boyars Publishers.

Jones, C., \& Spicer, A. (2009). Unmasking the entrepreneur. Cheltenham: Edward Elgar.

Hanlon, G. (2014). The entrepreneurial function and the capture of value: Using Kirzner to understand contemporary capitalism. Ephemera: Theory $\mathcal{E}$ Politics in Organization, 14(2), 177-195.

Hayek, F. A. (1945). The use of knowledge in society. American Economic Review, 35(4), 519-530.

Hayek, F. A. (1948) Individualism and economic order. London: Chicago University Press.

Hoselitz, B. F. (1951). The early history of entrepreneurial theory. Explorations in Economic History, 3(4), 193.

Kirzner, I. M. (1973). Producer, entrepreneur and the right to property. Symposium on the origins and development of property rights, Institute of Humane Studies, San Francisco, CA, January 1973.

Kirzner, I. M. (1997). Entrepreneurial discovery and the competitive market process: An Austrian approach. Journal of Economic Literature, 35(1), 60-85.

Lobel, F., Pamplona, N., Oliveira, F., \& Dall'Agnol, L. (2019, maio). Preços de corrida em SP sobem em dia de paralisação global de motoristas de Uber. Folha de S.Paulo. Retrieved from https://www1.folha.uol.com.br/ mercado/2019/05/precos-de-corrida-em-sp-sobem-em-dia-de-paralisacaoglobal-de-motoristas-de-uber.shtml

Mises, L. von. (1996). Human action: A treatise on economics (Vol. 2). Indianapolis: Liberty Fund.

Moraes, R. B. S., Oliveira, M. A. G., \& Accorsi, A. (2019). Uberização do trabalho: A percepção dos motoristas de transporte particular por aplicativo. Revista Brasileira de Estudos Organizacionais, 6(3), 647-681. doi:10.21583/ 2447-4851.rbeo.2019.v6n3.216

Murphy, A. E. (1986). Richard Cantillon: Entrepreneur and economist. Oxford: Oxford University Press.

Nascimento, L. F. (2016). O caso Uber no Brasil: Um ensaio de sociologia digital. Critical Reviews on Latin American Research, 5(1), 88-90.

O'Kane, S. (2019, Junho). Uber debuts a new self-driving car with more failsafes. The Verge. Retrieved from https://www.theverge.com/2019/6/12/ 18662626/uber-volvo-self-driving-car-safety-autonomous-factory-level 
Ortega, S. (2014). La política en manos de los empresarios: El imparable ascenso de la ideología del emprendedor. Revista Papeles de relaciones Ecosociales y cambio global, 127, 29-43.

Padilha, F., Stein, A., \& Lemos, C. (2017). Inovação e empreendedorismo. Revista Eletrônica em Gestão e Tecnologia, 3(1).

Polo, M. (1996). O livro das maravilhas: A descrição do mundo. Porto Alegre: L\&PM.

Pelegi, A. (2019, fevereiro). Justiça do Trabalho de BH reconhece vínculo de emprego entre Uber e motorista. Diário do Transporte. Retrieved from https://diariodotransporte.com.br/2019/02/04/justica-do-trabalho-debh-reconhece-vinculo-de-emprego-entre-uber-e-motorista/

Schumpeter, J. A. (1981). Teoria do esenvolvimento econômico. São Paulo: Abril Cultural.

Slee, T. (2017). Uberização: A nova onda do trabalho precarizado. São Paulo: Elefante.

Spencer, D. A. (2018). Fear and hope in an age of mass automation: Debating the future of work. New Technology, Work and Employment, 33(1), 1-12. doi:10.1111/ntwe.12105

Swedberg, R. (2000). The social science view of entrepreneurship: Introduction and practical applications. Entrepreneurship: The Social Science View, 7-44. Retrieved from http://people.soc.cornell.edu/swedberg/2000\% 20The\%20Social\%20Science\%20View.pdf

Taylor, F. W. (1990). Princípios de Administração Científic (8a ed.). São Paulo: Editora Atlas.

Vieta, M. (2014). The stream of self-determination and autogestión: Prefiguring alternative economic realities. Ephemera, 20(4), 781-809.

Walras, L. (1996). Compêndio dos elementos de economia política pura. São Paulo: Nova Cultural.

\section{AUTHOR NOTES}

Lucas Casagrande, PhD from the Graduate Program in Administration (PPGA), Federal University of Rio Grande do Sul (UFRGS); Martín A. M. Zamora, master from the Graduate Program in Administration (PPGA), UFRGS; Carlos F. T. Oviedo, PhD from the Graduate Program in Administration (PPGA), UFRGS. 
Lucas Casagrande is now professor at the Department of Administrative Sciences (DCA) of Federal University of Rio Grande do Sul (UFRGS); Martín A. M. Zamora is now PhD student of the Graduate Program in Administration (PPGA) of UFRGS; Carlos F. T. Oviedo is now alumnus of the Graduate Program in Administration (PPGA) of UFRGS.

Correspondence concerning this article should be addressed to Lucas Casagrande, Rua Washington Luíz, 855, 442, Centro Histórico, Porto Alegre, Rio Grande do Sul, Brazil, CEP 90010-460.

E-mail: lucas.casagrande@ufrgs.br

\section{EDITORIAL BOARD}

Editor-in-chief

Gilberto Perez

Associated editor

Simone Costa Nunes

Technical support

Vitória Batista Santos Silva

\section{EDITORIAL PRODUCTION}

Publishing coordination

Jéssica Dametta

Language editor

Daniel de Almeida Leão

Layout designer

Emap

Graphic designer

Libro 